\title{
Las Zwierzyniecki as an Element of the Composition of Green Areas in Białystok ${ }^{1}$
}

\author{
Dorota Gawryluk \\ https://orcid.org/0000-0002-5429-6658 \\ d.gawryluk@pb.edu.pl \\ Faculty of Architrecture, Biatystok University of Technology
}

\begin{abstract}
The article presents a historical and compositional analysis of the changes done to "Las Zwierzyniecki" (now a public park and nature reserve) in Białystok. It describes the stages of its transformation in the context of the changes done to the baroque composition of the Branicki residence and menageries from the $18^{\text {th }}$ to early $21^{\text {st }}$ century. An attempt was made to describe the historical and compositional design guidelines for the modern revitalisation of Las Zwierzyniecki.
\end{abstract}

Keywords: Las Zwierzyniecki, nature reserve, baroque composition, greenery, Białystok

The baroque palace and garden complex in Białystok is the main element of a broad landscape composition built at the behest of hetman Jan Klemens Branicki in the Biała river valley [Kucharczyk, Maroszek 1985, p. 57-70; Turecki 1996, p.13]. Over the years elements of this composition have been modified. The influence of the original baroque composition can be seen particularly strongly in the changes to the green areas of Białystok - the city parks created around the residence and in selected areas of the former Duży Zwierzyniec (greater menagerie), part of which formed the modern Las Zwierzyniecki.

\section{Research Objective and Current State of Research}

The objective of the research was to create historical and compositional design outlines for the revaluation of Las Zwierzyniecki. The objective was dictated by a real need for the city to make use of the areas of Las Zwierzyniecki (currently composed by the neighbouring areas of a public forest and a nature reserve) to connect the new university campus with the other academic locations and the city centre. The plans put forward by the local authorities so far have caused an uproar in the media and popular protests. This has brought to light the lack of useful interdisciplinary, historical and compositional analysis, which should precede design and execution of any work done in the area.

Issues connected with the history of Las Zwierzyniecki are presented from many points of view. In historical works on the spatial development of the city Las Zwierzyniecki is usually listed as an element of the baroque composition, which is as a whole testament to the city's identity [Dolistowska 2009; Oleksicki 1996, p. 81-84; Oleksicki 1992, p. 4-6; Turecki 1996, p. 7-16]. Many scholarly works on the baroque residence list the Duży Zwierzyniec (Greater Menagerie) as the background for courtly life [Nieciecki 1996, p. 53-58; Nieciecki 1999, p. 139-155; Dziubecki 2010; Oleńska 2011]. Historical research and analysis relating to the revaluation of palace gardens can be found in academic journals and conference proceedings [Nieciecki 2014, p. 7-118; Ogród Branickich ... 1998; Parki I ogrody zabytkowe... 2011; Sikora 2010, p. 32-42]. The history of Las Zwierzyniecki in the context of the Park Konstytucji 3 Maja ( $3^{\text {rd }}$ of May Constitution Park) is discussed in detail in "Katalog

1 The study has been implemented from the resources of the S/WBilŚ/2/16 statutory work financed by the Ministry of Science and Higher Education of Poland.

2 Roughly translatable as the the Zwierzyniec (menagerie) Forest. 
parków i ogrodów zabytkowych dawnego województwa białostockiego. Stan z 1988 roku" [Bończak Kucharczyk, Maroszek, Kucharczyk 2000; Bończak Kucharczyk, Maroszek, Kucharczyk 2019]. Studies concerning the green areas of Białystok are supplemented with numerous articles (both scholarly and in the press) and studies done by the students of Architecture and Landscape Architecture from the Białystok University of Technology [Zarzecki 2014]. There are no studies devoted to changes to the composition of Las Zwierzyniecki. Because a nature reserve has been created in this area, there are more studies devoted to its flora and fauna, as well as environmental protection.

\section{Methodology}

Revaluation of historical gardens and areas of historic greenery in the city is undertaken in leading academic centers in Poland and abroad. Scientific research on the issue of restoring historic gardens is carried out from different angles: preserving the spatial composition [Böhm 2016; Kadłuczka 2018], preserving the value of the originality of the historic garden [Majdecki, Majdecka-Strzeżek 2018; Zachariasz2006, 2008], planting, and landscape context [Zachariasz 2007, 2008; Myczkowski 2003]. Research is conducted on a study scale of individual gardens and cities [Łakomy 2012; Mitkowska, Hodor, Łakomy 2012], as well as on the general method of operation. The analysis of the legibility of the spatial composition of the Las Zwierzyniecki was based on the experiences of the Krakow School and other Polish researchers [Sikora 2011, 2010]. The topic of social participation in the process of restoration of historic gardens has been included also [Koller-Szumska 2010].

\section{History of the Development of the Spatial Composition of Las Zwierzyniecki in the context of the Branicki residence park complex}

Las Zwierzyniecki is an element of the spatial composition of forests and parks forming the "green wedge" leading into the city, towards the Branicki residence from the North-East.

\section{The Jan Klemens Branicki period (Baroque)}

The times of Jan Klemens Branicki is the golden age in the development of Białystok, especially his baroque residence [Oleksicki 1996, p. 84-86; Nieciecki 1996, p. 53-58; Nieciecki 1999, p. 139-155]. The baroque palace and garden complex was adjacent to the city from the west and north, from other sides it was surrounded by animals forests: deer (from the south connected with the main compositional axis of the assumption) and fallow deer (from the east). These, in turn, were continued by Duży Zwierzyniec - the favorite hunting place of Branicki and his guests. In the $18^{\text {th }}$ century Las Zwierzyniecki (known at the time as Duży Zwierzyniec) was a natural pine and spruce forest. At least 10 straight roads were marked out in the forest, crossing at various angles (Fig. 1A). They connected the residence with nearby villages and towns (Suraż, Bielsk), as well as an important compositional function, by forming lines of sight on attractive landscapes [Bończak Kucharczyk, Maroszek, Kucharczyk 2000, p. 39; Oleksicki 1996, p. 4-6]. Until the end of the $19^{\text {th }}$ century some of these roads vanished, probably because they fell into disuse [Bończak Kucharczyk, Maroszek, Kucharczyk 2019].

\section{The Partition Period}

During the partitions of Poland the baroque residence fell into decline. The palace gardens and deer menageries deteriorated. Due to gradual deterioration they lost all of their original splendour [Dolistowska 2009, p. 15-196].

In 1895-1897 Stary Park (the old park) was created on the north side of the palace complex. Until 1918 Stary Park was known as Ogród Miejski (municipal garden) and later, until 1939 - Ogród Miejski im. Józefa Poniatowskiego (the Prince Józef Poniatowski Municipal Garden). In its original form it was a naturalistic composition 
designed by Walerian Kronenberg with the cooperation of Teodor Chrzęński [Bończak Kucharczyk, Maroszek, Kucharczyk 2000, p. 37]. It was the main municipal park in Białystok at the time.

In the 1880 s the Russian authorities had a strategic road to Baranowicze built, which divided Las Zwierzyniecki attitudinally into an northern and southern part. At the end of the $19^{\text {th }}$ century a complex of buildings known as "Rozkosz" (delight), which served entertainment purposes, was built in place of the former forestry. A horse-drawn streetcar brought people to it running along one of the original trails (now the 11 Listopada street) [Maps of historical Białystok; Dolistowska 2009, p. 188-189]. The Rozkosz complex quickly became popular among the people of Białystok because of the open air parties, theatre and cabaret performances organised there. The place became attractive and summer houses began appearing nearby. The forest was decimated during World War I. A German military cemetery was placed in its north-western part. The cemetery no longer exists. In its place stands the building of the Białystok Radio station.

\section{The Mid-War Period}

In 1918-1939 the city authorities wanted to improve the city's image. This was largely to be achieved through modernisation and the creation of new green areas.

Park Planty was established in 1930-1938 in place of the old gardens and fallow deer menagerie surrounding the palace from the east and the south. They were designed by Stanisław Grala. The modernist character of the park's composition is seen in its broad diagonal main boulevard following an old ash and maple lined avenue [Bończak Kucharczyk, Maroszek, Kucharczyk 2000, p. 36; Poskrobko 1988, p. 21-23; Dolistowska, Szczygieł-Rogalska, Tomalska 2008, p. 84]. The line of the main prospect boulevard (the park's modernist axis) is emphasised by rectangular lawns with flowerbeds and lines of white cedar trees. Park Planty connected functionally and compositionally Park Stary on its north side with Las Zwierzyniecki in the south. In the second half of the 1930s Stary Park (at the time known as Ogród Miejski im. J. Poniatowskiego) was rebuilt in a modernistic style following the design of Stanisław Życieński-Zadora [Bończak Kucharczyk, Maroszek, Kucharczyk 2000, p. 38]. A rectangular plaza was created in front of the Dom Ludowy (People's House, designed by architect Jan Girin). Modern public parks (Park Stary and Planty with its boulevards) surrounded the baroque palace gardens. Their special arrangement refers to the compositional directions of the original composition.

The first attempts at bringing order to Las Zwierzyniecki in the mid-war period was the creation of a "living monument" giving its northern part the name Park Konstytucji 3 Maja (3 May Constitution Park) [Bończak Kucharczyk, Maroszek, Kucharczyk 2000, p. 40]. On 3 May 1921, on the $130^{\text {th }}$ anniversary of the creation of the 3 May Constitution, three oaks, surrounded by a circle of 11 linden, were planted with ceremony at the junction of five footpaths. In 1924 Stanisław Życieński-Zadora created designs for a city park including the whole area of Zwierzyniec (Fig. 1B). The main element of the composition was a new avenue lined with a double line of trees (it was and almost straight continuation of the main avenue of Planty, at the same time matching the original radial distribution of the avenues in Duży Zwierzyniec) [Dolistowska 2009, p. 242-243]. On both sides of the main axis a network of footpaths developed, opening views on the forest. The geometric contrast between the straight main line of the composition and the twisting side paths was emphasised by three circular intersections on the main avenue. In 1930 renovation of Zwierzyniec in the modernist style began, based on a detailed plan by the city's first engineer J.B. Rybołowicz, which followed, in its main assumptions the 1924 design (Fig. 1C) [Bończak Kucharczyk, Maroszek, Kucharczyk 2000, p. 40]. The widened Aleja 11 Listopada (11 November Avenue) retained its original course. The new main avenue started at a circular junction connecting Zwierzyniec and Planty with three further such junctions emphasising its straight line. The first of them contained a monument and was encircled by an elliptical footpath [Bończak-Kucharczyk, Maroszek 2019]. In 1930 a monument was erected at the first junction in honour of dead officers and soldiers from the $42^{\text {nd }}$ infantry regiment created by brothers Jakub and Kazimierz Juszczyk. The pathway system was complemented by avenues running along interesting groups of trees and shrubbery, a viewing platform on a small hill on the eastern side with a view on the ponds and stream in the north-eastern part [Bończak Kucharczyk, Maroszek, Kucharczyk 2000, p. 38; Maps of historical Białystok: 1937 map of Białystok, World War Il era German map of Białystok]. In the 1920s and 1930s a sports complex was created on the west side [Bończak Kucharczyk, Maroszek, Kucharczyk 2000, p.38; Dolistowska 2009, p. 243]. The sports complex consisted of: city stadium (1926), 
tennis courts, parachute tower. In 1920 a military cemetery was created at the junction of Al. 11 Listopada and Zwierzyniecka [Bończak Kucharczyk, Maroszek, Kucharczyk 2000, p. 38]. A monumental memorial created by J. Girin was erected in the cemetery in 1932. The cemetery stood out of its surroundings, it was surrounded with regular lines of cedars and oaks.

The division of Las Zwierzyniecki into two parts was established in this period - the more park-like northern part and a more forest-like southern part. The meridional division created by Aleja 11 Listopada was not a functional problem, because the traffic was limited [Dolistowska 2009, p. 243]. A bus line ran along Aleja 11 Listopada talking passengers to the restaurants in the former "Rozkosz" complex.

During World War II, in 1940 the Russian army destroyed the monument in honour of soldiers of the 42. infantry regiment, while the Germans cut down nearly 50ha of Las Zwierzyniecki to build an airfield in Krywlany [Bończak Kucharczyk, Maroszek, Kucharczyk 2000, p. 40], what is presented on German air photography from the final period of World War II.

\section{After World War II}

After World War II, even though the Branicki palace and its gardens were almost entirely destroyed, a decision was made to rebuild the baroque complex to preserve the cultural value of the cityscape. The residence was renovated in stages Nieciecki 2014, 7-118; Ogród Branickich 1998; Parki i ogrody zabytkowe 2011; Sikora 2010, p. 32-42; Sikora 2011].

The parks surrounding the residence were also renovated. The basic composition of Park Stary and Planty with Bulwary Kościałkowskiego (Kościałkowski Boulevard) created after World War Two remained true to the mid-war plan [Bończak Kucharczyk, Maroszek, Kucharczyk 2000, p. 36; Gawryluk 2015, p. 74-80]. The new elements of the plaza in front of the Aleksander Węgierko Theatre in Park Stary follow a modernist axial composition. In 2003-2007 the plaza was modernised (new pavement, fountain, lighting, street furniture), in 2014 a sculpture by Albin Sokołowski was placed in the centre of the plaza.

Changes to the visibility of the main axis of Planty were made by placing and removing small elements located along it. A monument in honour of the Soviet Army by Ślusarczyk and Danka, placed in the highest point of the axis was erected in 1951 and torn down in the 1990s. In 2000 the main fountain was modernised - the lighting sequences were harmonised with water jets. Other elements were also modified, which do not influence the legibility of the main compositional axis of Planty. In place of a so called "dry" fountain, a new playground was built following an individual project. The Serce (heart) pond nearby the rosary was also revitalised.

In the early plans developed for the city of Białystok after World War II Park Konstytucji 3 Maja (Park Zwierzyniecki at the time) and Las Zwierzyniecki were supposed to be a large green complex fitting the pre-war concept of a garden city proposed for Białystok [Oleksicki 2003, p. 98-107; Dolistowska 2009, p. 99-105+ graphic attachment].

In the 1960s Park Zwierzyniecki was excluded from the municipal area of Las Zwierzyniecki. Similarly to the other city parks it was under constant care and conservation. 30.12.1986 r. Park Zwierzyniecki was registered as a historical monument under the number A-138. The basic spatial composition of the park coincided with the pre-war concept. The course of the side alleys changed, but the main axis remained clear. The functional program for the park was modified [Bończak Kucharczyk, Maroszek, Kucharczyk 2000, p.41]. Construction in the 1960s and 1970s included: a small zoo called "Accent ZOO", and amphitheatre, fitness trail. At the turn of the $20^{\text {th }}$ and $21^{\text {st }}$ century a number of work projects were completed referring to the history of the park and further modernising its functional programme [Gawryluk 2015, p. 79]. New and reconstructed monuments were erected at the junctions (a memorial stone was erected in 2000 in honour of Polish soldiers murdered by the Soviets, as well as a replica of the monument honouring the soldiers of the 42 . infantry regiment, who were killed in the war of 1920, created by brothers Jakub and Kazimierz Juszczyk, made in 1997 by Krzysztof Jakubowski and) and new pavements were laid. In 2007 the presence of a 3 May Constitution monument was re-established by placing a symbolic pyramid and planting additional trees. In 2010 a new playground was built and in 2010-2013 the existing small zoo was modernised.

In the 1970s 11 Listopada street was paved with asphalt and the roundabout at its end was removed. This divided the two parts of Las Zwierzyniecki with a street with automobile traffic. The western part of the municipal 
forest, which is separated from the overall spatial composition, is now a green buffer between 11 Listopada and Świerkowa streets (and the nearby Białystok University of Technology and University of Białystok buildings) (Fig. 1D). In the eastern part of Las Zwierzyniecki an avenue remains leading to a circular junction where a memorial stone was placed in 1965 [Bończak Kucharczyk, Maroszek, Kucharczyk 2000, p. 41]. The stone was erected in honour of cpt. Stanisław Skarżyński, who flew over the Atlantic in 1933. The stone was moved to the junction from the square between the pre-war Park Zwierzyniecki and the barracks.

Some of the old footpaths in Las Zwierzyniecki disappeared or were removed. Over the years the footpath encircling the junction also lost its legibility (Fig.1D) [Zarzecki 2014, p. 63-64].

On 14 June 1996 a decree by the minister of the environment created a nature reserve called "Las Zwierzyniecki" with an area of 33.8 ha in the north-western part of the municipal forest. It was created in view of the scientific and educational value of its marshy forests characteristic for the region.

At the turn of the first and second decade of the $21^{\text {st }}$ century the first stage of a new University of Białystok campus was built near the southern edge of Las Zwierzyniecki, designed by architect Marek Budzyński and his team. To create lines of communication between the various universities and the city centre, a concept was proposed called Park Czterech Uniwersytetów (the Four Universities Park) to be built in Las Zwierzyniecki.

\section{Stages of development of the park composition of Las Zwierzyniecki}

The stages of transformations in Las Zwierzyniecki were established based on an analysis of the history of development of the area, archival plans and maps of Białystok, as well as modern topography and flora.

Table 1. Stages of development of the park composition of Las Zwierzyniecki

\begin{tabular}{|c|c|c|}
\hline & Stage & Characteristics of the stage \\
\hline 1 & $18^{\text {th }}$ to early $20^{\text {th }} \mathrm{c}$. & $\begin{array}{l}2^{\text {nd }} \text { half of } 18^{\text {th }} \mathrm{c} \text {. baroque composition of Duży Zwierzyniec. } \\
\text { Multidirectional, multi-axis network of forest roads and paths, } \\
\text { communication and landscape connections. In the } 19^{\text {th }} \mathrm{c} \text {. the composition } \\
\text { loses its legibility. }\end{array}$ \\
\hline 2 & Mid-war period & A modernist park connected with a landscape system, clear internal views \\
\hline 3 & After World War II & $\begin{array}{c}\text { The legibility of the modernist composition deteriorates. } 1960 \text { s - the } \\
\text { municipal forest is separated out - ongoing succession. } 1996 \text { - creation } \\
\text { of a nature reserve in the north-eastern part of Las Zwierzyniecki - natural } \\
\text { succession. }\end{array}$ \\
\hline
\end{tabular}

\section{Analysis of the modern composition. Results}

The modern composition of Las Zwierzyniecki is largely gone. Despite its forest character the main element of the modern composition are the four clear avenues radially diverging from the main circular junction. The oval avenue surrounding this junction at a distance of $110 \mathrm{~m}$, which was a characteristic element of the modernist concept, is now almost invisible, its old course is partly visible in tree plantings. Marcin Zarzecki indicated in his analysis that the double circle of trees is broken in place of the edge of the German wartime airstrip [Zarzecki 2014, p. 62-63]. The composition was not completed with new plantings after the war. The peripheral avenue is all the less legible, as it does not currently function as walking path.

The main junction with the four converging avenues and the semi-circular junction closing the main avenue are inside or at the edge of the nature reserve (Fig. 2A). Fallen trees are not removed and can be seen in the protected part of the forest (Fig. 2B).

In the part of the municipal forest between 11 Listpoada and Świerkowa there are only unplanned transverse footpaths. 


\section{Propositions for design guidelines from a historical-compositional perspective. Discuss}

Las Zwierzyniecki is an integral part of the green areas connected with the $18^{\text {th }}$ century Branicki residence in Białystok. Even though it is the only city park which is not legally protected as a historical monument, because of its importance for the whole composition, it should be treated like the other parks [Zachariasz 2019, 2007, 2006; Kadłuczka 2018, Łakomy 2012]. In this sense it would be a good practice to include the guidelines of the Florence Charter for forest revitalisation [Zachariasz 2008, p. 150-161].

Las Zwierzyniecki is strongly connected with the history of the city and is an important element of its identity. At the same time it is obvious that historical park complexes undergo modification as their functions and surroundings change. We often see new identities arise or be introduced to a historical context in order to preserve and protect it [Bohm 2015; Myczkowski 2003]. Introducing new walking paths into the municipal forest would be expedient from this point of view, because it would fit better into the old park composition, restoring its legibility.

Białystok is an academic city. Currently many university buildings have accumulated around Las Zwierzyniecki. Walking lanes placed with respect for the ecological and cultural values of the forest would be an answer to the current needs of the city. Revaluation of a forest, which keeps to a certain standard brings various benefits: cultural (recreating the legibility of the historical composition), functional (improving communication and adding recreational value), social (increased sense of security) and economic (improving attractiveness for tourists; greater attractiveness of an area increases the value of surrounding real estate).

Suggested design guidelines taking into account historical and compositional values for the revitalisation of Las Zwierzyniecki:

- reducing the division of the forest into two parts by 11 Listopada street and its isolation from Park Konstytucji 3 Maja by Zwierzyniecka street (e.g. by changing the organisation of traffic in 11 Listopada and by vertically separating pedestrian and recreational traffic from automobile traffic in Zwierzyniecka by building a tunnel, elevated footbridge, gangway connecting both parts of the park, or other similar solutions);

- improving the legibility of main park interiors: circular junctions, the peripheral avenue and the radial avenues. In the contended area where avenues and junctions run along the limits of the nature reserve an interdisciplinary expert panel should be created to establish the best course of action [Zachariasz 2019, 2008, p. 154] ;

a design works should be inspired by the history of changes to the spatial and landscape complex [Zachariasz 2014$]^{4}$;

- managing the forest and replenishing the tree stand in a public park should honour the historical values of the place;

- improving the standard of functional furnishings of the walking avenues and choice of materials should honour cultural values ${ }^{5}$.

Establishing the final design guidelines should be made by committee of experts in a variety of various fields (architecture, landscape architecture, history, environmental protections, urban planning, etc.) The implementation should be preceded by consultations with the community to explain the concepts [Szumska-Koller 2010,

3 A. Zachariasz presents examples of contested (protection of a nature reserve vs protection of a historical monument) parks in Warsaw, as well as positive solutions in Pieskowa Skała in Ojców National Park, where vegetation is regulated to reveal a view of the castle.

4 All further changes to the composition of public parks connected with the palace gardens in Białystok were a continuation of these gardens providing a continuous "green wedge" reaching all the way to the city centre. Recreated or transformed parks were not copies of the baroque composition, but were inspired by it and at the same time were an expression of their respective epochs and a reflection of contemporary trends (naturalist and later modernist composition of Park Stary; modernist composition of Planty and Park Konstytucji 3 Maja). The entirety of the complex formed a coherent spatial composition formed of elements in different styles. In this sense, modern operations in Las Zwierzyniecki should also be an expression of the modern approach to the design of public parks, where inspiration for a new concept is drawn from the history of the place and its old identity, which is given a new identity concurrent with the identity of Białystok.

5 The functional program suggested for Las Zwierzyniecki cannot conflict with the historical and natural character of the place (e.g. in terms of noise, traffic, pollution, etc.) Suggested functions include: historical function (preserving the legibility and continuity of the green wedge clarity of composition), communication (walking routs: university - city centre - housing quarters), entertainment (active and passive), science (nature reserve), education, tourism (cultural landscape). 

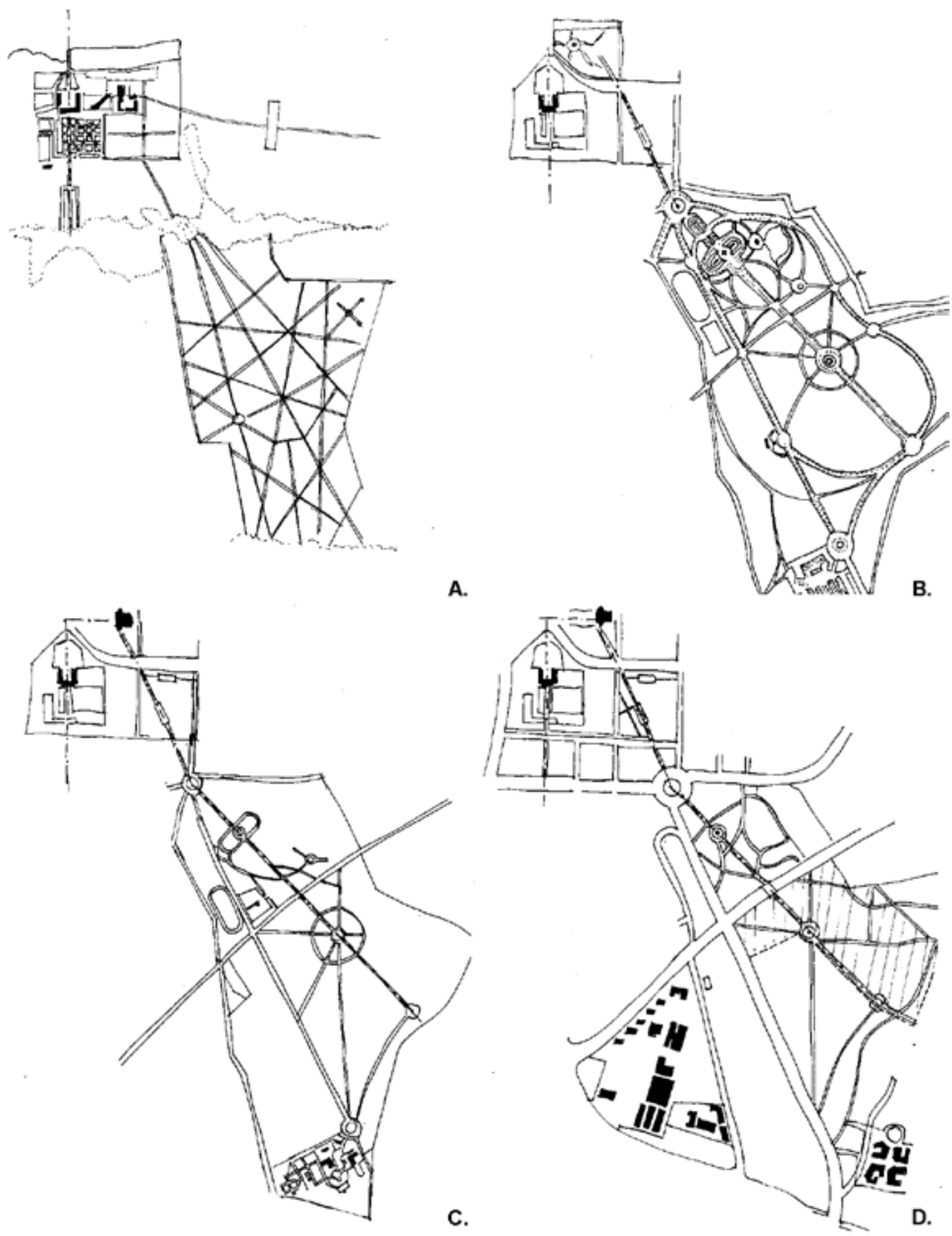

Fig. 1. Changes to the spatial composition of Las Zwierzyniecki in Białystok: A) Duży Zwierzyniec of the baroque Branicki residence, B) Design for Park Zwierzyniecki from 1924, C) the Park and Las Zwierzyniecki in 1937, D) Current state of Las Zwierzyniecki (all illustrations made by the author based on literature of main subject, 2018). 
p. 57-60] ${ }^{6}$, especially after the lack of public consultations in 2017 . The conflict situation resulted in halting the process of park revaluation.

\section{Conclusions}

Knowing the historical spatial composition of Las Zwierzyniecki in Białystok should be the main inspiration for the project of its revaluation. The proposed guidelines are supposed to help preserve the cultural values of the place, while at the same time giving it a modern dimension - a testimony to the times. The designs for the forest should be characterised by particular care for its existing natural and cultural value, important for the place itself, but also for the continuation of the baroque composition initiated in the $18^{\text {th }}$ century by Jana Klemens Branicki.

A)

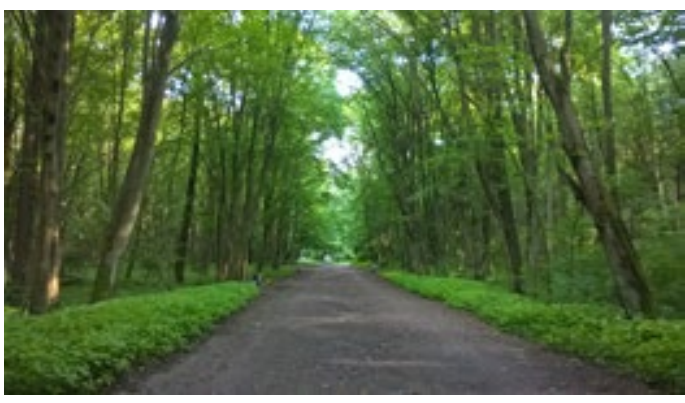

B)

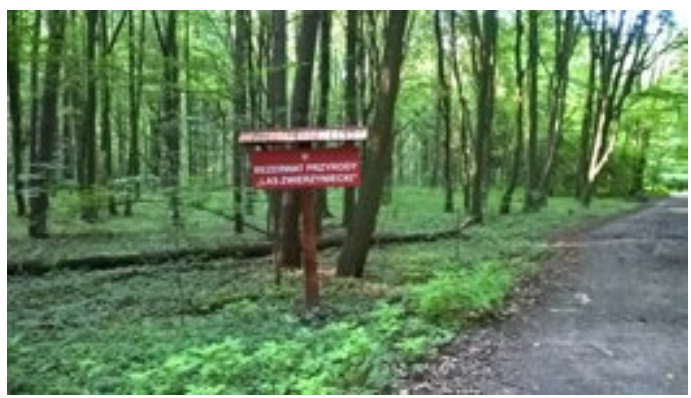

Fig. 2. Contemporary Las Zwierzyniecki: A) the main avenue closed by main junction, B) the nature reserve "Las Zwierzyniecki" (all photos made by the author, 2018)

\section{References}

[1] Böhm A. 2016. O czynniku kompozycji w planowaniu przestrzeni, Wydawnictwo PK, Kraków

[2] Bończak-Kucharczyk E., Maroszek J., Kucharczyk K. 2000. Katalog parków i ogrodów zabytkowych dawnego województwa białostockiego stan z 1988r.), Prace Białostockiego Towarzystwa Naukowego Nr 47, Białystok

[3] Bończak-Kucharczyk E., Maroszek J., Białystok Park Zwierzyniecki, http://www.ogrodowy.minigo.pl/index.php/page/ bia-ystok-park-zwierzyniecki, (access July 2019)

[4] Dolistowska M. 2009. W poszukiwaniu tożsamości miasta: architektura i urbanistyka Biategostoku w latach 1795-1939, Oficyna Wydawnicza Politechniki Białostockiej, Białystok

[5] Dolistowska M., Szczygieł-Rogalska J., Tomalska J. 2008. Białystok nie tylko kulturalny. Okres powojenny lata 1944-1946, Instytut Wydawniczy Kreator, Białystok

[6] Dziubecki T. 2010. Programy symboliczne i funkcje ceremonialne rezydencji magnackich. Puławy-Biatystok-Radzyń Podlaski-Lubartów w latach 1730-1760, Muzeum Pałac w Wilanowie, Warszawa

[7] Gawryluk D. 2015. Historical Public Parks in Podlasie and their Current Day Modernisation, Formation of Urban Green Areas Nr 1, 2015, 74-80

[8] Kadłuczka A. 2018. Ochrona dziedzictwa architektury i urbanistyki. Doktryny, teoria, praktyka. Wydawnictwo PK, Kraków

[9] Koller-Szumska J. 2010. Społeczna promocja prac rewaloryzacyjnych i pozyskiwanie środków na prace realizacyjne - na przykładzie Ogrodu Branickich w Białymstoku, Kurier Konserwatorski, 7/2010, 57-60

[10] Kucharczyk K., Maroszek J. 1985. Barokowa kompozycja w dolinie rzeki Białej w XVIII w., Studia i Materiały do Dziejów Miasta Białegostoku T. IV, 1985, 57-70

[11] Łakomy K., 2012. Ogrody w krajobrazach miast (cz. 2, od pot. XVIII do XX w.), [w:] Historyczne i wspótczesne ogrody w krajobrazie miasta, red. A. Mitkowska, K. Hodor, K. Łakomy, Czasopismo Techniczne, z. 6-A, rok 109, Wydawnictwo PK, Kraków 
[12] Majdecki L., Majdecka-Strzeżek A. 2018. Ochrona i konserwacja zabytkowych założeń ogrodowych, PWN, Warszawa

[13] Maps of historical Bialystok, http://igrek.amzp.pl/maplist.php?cat=TPCE, (access July 2019)

[14] Mitkowska A., Hodor K., Łakomy K. (ed.) 2012. Historyczne i wspótczesne ogrody w krajobrazie miasta, Czasopismo Techniczne , z. 6-A, rok 109, Wydawnictwo PK, Kraków.

[15] Myczkowski Z. 2003. Krajobraz wyrazem tożsamości w wybranych obszarach chronionych w Polsce, Wydawnictwo PK, Kraków

[16] Nieciecki J. 1996. Opowieści o "Polskim Wersalu", Biuletyn Konserwatorski Województwa Białostockiego, Issue 2, 1996, 53-58

[17] Nieciecki 1999. Opowieści o "Polskim Wersalu", Biuletyn Konserwatorski Województwa Biatostockiego, Issue 5, 1999, 139-155

[18] Nieciecki J. 2014. Rewaloryzacja Ogrodu Dolnego w Ogrodzie Branickich w Białymstoku. Propozycja zakresu i rodzaj prac, Biuletyn Konserwatorski Województwa Białostockiego, Issue 20, 2014, 7-118

[19] Ogród Branickich w Białymstoku: badania, projekty, realizacja, 1998. Studia i Materiały - Ośrodek Ochrony Zabytkowego Krajobrazu. Narodowa Instytucja Kultury. Ogrody 4(10), Warszawa

[20] Oleksicki A. 2003, Pierwszy powojenny plan Białegostoku autorstwa Ignacego Felicjana Tłoczka a późniejszy rozwój miasta, Biuletyn Konserwatorski Województwa Białostockiego, p. 98-107.

[21] Oleksicki A. 1996. Białystok i okolice - nowo pozyskane źródła kartograficzne z archiwów rosyjskich, Biuletyn Konserwatorski Województwa Białostockiego, 1996, 81-84

[22] Oleksicki A. 1992. Nowe źródło do dziejów rozwoju przestrzennego Białegostoku, Białostocczyzna, z. 4/28 /1992, p. 4-6.

[23] Oleńska A. 2011. Jan Klemens Branicki "Sarmata nowoczesny". Kreowanie wizerunku poprzez sztukę, Instytut Sztuki PAN, Warszawa 2011.

[24] Parki i ogrody zabytkowe - ochrona i konserwacja. Ogród Branickich w Biatymstoku, historia rewaloryzacji: konferencja międzynarodowa 9-10 września 2010, Urząd Miejski w Białymstoku, Białystok 2011.

[25] Poskrobko J. 1988, Planty Stanisława Grali, Białostocczyzna, z. 4/12 /1988, p. 21-23.

[26] Sikora D. 2011. Konserwacja ogrodów regularnych XVII i XVIII w., Warszawa.

[27] Sikora D. 2010. Specyfika dziatań konserwatorskich w ogrodach regularnych, Kurier Konserwatorski, 2010, nr 7, p. 32-42.

[28] Turecki A. 1996. Plan du chateau et de la ville de Białystok avec ses environs, Ochrona reliktów urbanistycznych Białegostoku, Zeszyty Naukowe Politechniki Białostockiej, Nauki Techniczne Nr 108, Architektura Z. 16, Białystok, p. 7-16.

[29] Zachariasz A. 2006. Zieleń jako wspótczesny czynnik miastotwórczy ze szczególnym uwzględnieniem roli parków publicznych, Wydawnictwo PK, Kraków.

[30] Zachariasz A. 2008. Zabytkowe ogrody - problemy rewaloryzacji, utrzymania i zarządzania w świetle Karty Florenckiej, PKKK 2008, nr 10, p. 150-161.

[31] Zachariasz A. 2007. Zabytkowe parki i ogrody publiczne we wspótczesnym krajobrazie - problemy rewaloryzacji, Przyroda i Miasto 2007, t. 10, cz. 1, s. 328-354.

[32] Zachariasz A. 2014. O kształtowaniu systemów terenów zieleni miejskiej w kontekście zielonej infrastruktury, ze szczególnym uwzględnieniem Krakowa, [w:] Zielona infrastruktura miasta, red. A. Pancewicz, Gliwice, p. 59-88.

[33] Zachariasz A. 2019. Zielony Kraków dla przyjemności i pożytku Szanownej Publiczności, Wydawnictwo PK, Kraków.

[34] Zarzecki M. 2014, Projekt rewaloryzacji Parku Konstytucji 3 Maja oraz Lasu Zwierzynieckiego w Biatymstoku z uwzględnieniem warunków wilgotnościowych środowiska, magisterska praca dyplomowa obroniona w 2014 w Politechnice Białostockiej, promotor dr hab. inż. Aleksander Kiryluk prof. PB, Białystok.

\section{Las Zwierzyniecki jako element kompozycji terenów zieleni Białegostoku}

Streszczenie: W artykule przedstawiono historyczną i kompozycyjną analizę zmian dokonanych w "Lesie Zwierzynieckim" (obecnie park publiczny i rezerwat przyrody) w Białymstoku. Opisano etapy jego transformacji w kontekście zmian dokonanych w barokowym układzie rezydencji Branickich od XVIII do początku XXI wieku. Podjęto próbę opisania historycznych i kompozycyjnych wytycznych projektowych współczesnej rewaloryzacji Lasu Zwierzynieckiego.

Słowa kluczowe: Las Zwierzyniecki, rezerwat przyrody, kompozycja barokowa, tereny zieleni, Białystok 